\title{
Exploring the Reasons of Popularity of Time-Travel TV Series in Chinese University Students
}

\author{
Jianhua Huang \\ School of Journalism and Communication, Southwest University, Chongqing, China \\ Email: xuedadahilda@163.com
}

Received 12 June 2015; accepted 27 June 2015; published 30 June 2015

Copyright (C) 2015 by author and Scientific Research Publishing Inc.

This work is licensed under the Creative Commons Attribution International License (CC BY).

http://creativecommons.org/licenses/by/4.0/

(c) (i) Open Access

\begin{abstract}
Time-travel TV series is a new type between science fiction TV series and myth TV series (Li, 2012). In these years, more and more university students are addicted to it (Sun, 2011). To understand the reasons why time-travel TV series is so popular in those young groups, this paper adopts the structure of close-ended and the Likert-Scale five-point measure questionnaire. We choose 400 university students as the respondents, and they all come from the Southwest University. The questionnaires are randomly delivered to students from different majors and grades. The results are as follows: 1) time-travel novel's prevalence lays the foundation for the time-travel dramas; 2) romantic love and heroism are the second main reasons of its success, followed by eye-pleasing actors in the TV dramas, and Post-modern aesthetic idea; 3 ) compared with historical TV drama, time-travel TV series is much more popular, and there are even $24.4 \%$ respondents learning history from time-travel TV series; 4) 57\% students think time-travel TV dramas have some scientific basis, and some of them (104 students) still believe that those stories can be happen in real life.
\end{abstract}

\section{Keywords}

Time-Travel TV Series, University Students, Popularity

\section{Introduction}

Time-travel TV series means the TV series' theme concerning the time traveling or room traveling (Li \& Guo, 2012). It is becoming one of the most popular TV programs among the contemporary China (Cai \& Xu, 2012). Recently, traveling through time and space has gained an amount of followers with a couple of these TV series on air (Dong, 2011). It is no doubt that TV series featuring time-traveling roles has expanded its audiences, but 
thereupon are controversial rumors and public outcry that it is a distortion and a immoralism to history, with a certain amount of people holding varied understandings and points of view (Sun, 2011). This study illustrated detailed explanation on how college students considered the time-travel TV series in today's China based on conducted questionnaires and analyzed statistics to study about the impact it had on adolescents.

\section{Methodology}

This study adopts the structure of close-ended and the Likert-Scale five-point measure questionnaire. Each item is given a 5 -point scale with $1=$ strongly disagree, $2=$ disagree, $3=$ Neither agree nor disagree, $4=$ agree, and 5 = strongly agree. Each questionnaire took $20-25$ minutes to complete. The questionnaire was developed in Chinese. 400 questionnaires were randomly distributed to students in Southwest University from different majors and grades, and 372 valid questionnaires were recovered, with a total recovery rate of $93 \%$.

\section{Results}

\subsection{Descriptive Statistics}

There are 220 females and 152 males. The respondents for number of time-travel TV series watched are presented in Table 1. Most of them have watched time-travel TV series, only 3\% students have never seen that before.

\subsection{The Reasons of Popularity of Time-Travel TV Series in Chinese University Students}

Table 2 displays the reasons why time-travel TV series are popular in Chinese university students. In this table, there are 372 questionnaires available, each item is given a 5-point scale with $1=$ strongly disagree, $2=$ disagree, $3=$ slightly agree, $4=$ agree, and $5=$ strongly agree. The mean score for each item was used to describe the strength of each item. There are six items' mean scores higher than 3, and there are four items' mean scores lower than 3. The item "It is promoted by time-travel fictions and youth literature" recorded the highest mean score $(\mathrm{M}=3.65)$. The second highest mean score is "Romantic love and heroism are the main reasons of its success" $(M=3.45)$, and the third highest mean score is "I had attracted by the large-scale of advertisement before watched" ( $M=3.43)$, followed by "A large number of eye-catching TV stars attract me to watch it" $(M=$ 3.34), "The content of time-travel TV series is entertaining" $(M=3.25)$, and "Post-modern style conforms to the aesthetic idea of modern young people" $(\mathrm{M}=3.21)$. The lowest mean score is item "I learn some history from time-travel TV series" $(\mathrm{M}=1.81)$.

\section{Discussion}

Based on the results obtained above, most of the university students have watched time-travel TV series before, and $75 \%$ students have watched at least one time-travel TV series. There are even $10 \%$ students crazing about it, because they say that they have watched more than 5 time-travel TV series (Table 1).

There are $72 \%$ students agree with the idea "Romantic love and heroism are the main reasons of its success." Imagination in time-travel TV series creates a chance for the young to fulfill a dream that's hard to achieve in reality. It's usually a "dream of heroism come true". It succeeded in satisfying teenagers' desire for true love and success which, however, is suffering a great loss in their real life. A strong feeling of resonance is inspired

\begin{tabular}{|c|c|c|c|}
\hline Items & Options & $\begin{array}{l}\text { Number of people } \\
\text { (the total is 372) }\end{array}$ & Percentage (the total is 372 ) \\
\hline \multirow[t]{5}{*}{ Number of time-travel TV series watched } & 0 & 11 & $3 \%$ \\
\hline & $0-1$ & 83 & $22 \%$ \\
\hline & $2-3$ & 138 & $37 \%$ \\
\hline & $4-5$ & 101 & $27 \%$ \\
\hline & More than 5 & 39 & $10 \%$ \\
\hline
\end{tabular}


Table 2. The reasons of popularity of time-travel TV series in Chinese university students.

\begin{tabular}{|c|c|c|c|c|c|c|}
\hline Item & $\begin{array}{l}\text { Strongly disagree } \\
(\%)\end{array}$ & Disagree (\%) & $\begin{array}{l}\text { Slightly agree } \\
(\%)\end{array}$ & Agree (\%) & $\begin{array}{l}\text { Strongly agree } \\
(\%)\end{array}$ & Mean \\
\hline \multirow{2}{*}{$\begin{array}{l}\text { Romantic love and heroism are the main } \\
\text { reasons of its success. }\end{array}$} & 23 & 81 & 52 & 138 & 78 & 3.45 \\
\hline & $6.20 \%$ & $21.80 \%$ & $14.00 \%$ & $37.10 \%$ & $20.90 \%$ & \\
\hline \multirow{2}{*}{$\begin{array}{l}\text { It is promoted by time-travel fictions and } \\
\text { youth literature }\end{array}$} & 42 & 13 & 80 & 136 & 101 & 3.65 \\
\hline & $11.30 \%$ & $3.50 \%$ & $21.50 \%$ & $36.60 \%$ & $27.10 \%$ & \\
\hline \multirow{2}{*}{$\begin{array}{l}\text { A large number of eye-catching TV stars } \\
\text { attract me to watch it }\end{array}$} & 49 & 63 & 49 & 135 & 76 & 3.34 \\
\hline & $13.20 \%$ & $16.90 \%$ & $13.20 \%$ & $36.30 \%$ & $20.40 \%$ & \\
\hline \multirow{2}{*}{$\begin{array}{l}\text { I had attracted by the large-scale of } \\
\text { advertisement before watched. }\end{array}$} & 16 & 83 & 67 & 137 & 69 & 3.43 \\
\hline & $4.30 \%$ & $22.30 \%$ & $18.00 \%$ & $36.80 \%$ & $18.60 \%$ & \\
\hline \multirow{2}{*}{$\begin{array}{l}\text { Post-modern style conforms to the } \\
\text { aesthetic idea of modern young people }\end{array}$} & 4 & 140 & 56 & 118 & 54 & 3.21 \\
\hline & $1 \%$ & $37.70 \%$ & $15.10 \%$ & $31.70 \%$ & $14.50 \%$ & \\
\hline \multirow{2}{*}{$\begin{array}{l}\text { The content of time-travel TV series is } \\
\text { entertaining }\end{array}$} & 35 & 94 & 52 & 125 & 66 & 3.25 \\
\hline & $9.40 \%$ & $25.30 \%$ & $14 \%$ & $33.60 \%$ & $17.70 \%$ & \\
\hline \multirow{2}{*}{$\begin{array}{l}\text { I like historical TV shows more than } \\
\text { time-travel TV series. }\end{array}$} & 162 & 98 & 49 & 47 & 16 & 2.08 \\
\hline & $43.50 \%$ & $26.30 \%$ & $13.20 \%$ & $12.60 \%$ & $4.30 \%$ & \\
\hline \multirow{2}{*}{$\begin{array}{l}\text { I learn some history from time-travel TV } \\
\text { series }\end{array}$} & 192 & 89 & 63 & 26 & 2 & 1.81 \\
\hline & $51.60 \%$ & $24 \%$ & $16.90 \%$ & $7.00 \%$ & $0.50 \%$ & \\
\hline \multirow{2}{*}{ Time travel has its scentific background } & 60 & 100 & 115 & 78 & 19 & 2.72 \\
\hline & $16.10 \%$ & $26.90 \%$ & $30.90 \%$ & $21.00 \%$ & $5.10 \%$ & \\
\hline \multirow{2}{*}{$\begin{array}{l}\text { I believe time travel could be happen } \\
\text { in real life }\end{array}$} & 159 & 109 & 72 & 28 & 4 & 1.95 \\
\hline & $42.70 \%$ & $29.30 \%$ & $19.40 \%$ & $7.50 \%$ & $1.10 \%$ & \\
\hline
\end{tabular}

between the audiences and the composers while watching the programs $(\mathrm{Li}, 2012)$. The youngsters would eventually get a release of their restrained emotions and fulfillment of their dissatisfaction after feeling very much into the plot. We take this as the real reason behind the time-travel TV craze.

$85.2 \%$ students $(27.1 \%$ strongly agree, $36.6 \%$ agree, $\mathrm{M}=3.65)$ believe that time-travel novels and youth literature could promote the prevalence of time-travel TV dramas. At present, many popular time-travel dramas are adapted from time-travel novels. Time-travel novel's creation and issue have a long history and its prevalence lays the foundation of the time-travel dramas. And the romantic entanglement is throughout the novels and dramas, which caters to the tastes of modern young people (Jiang, 2006).

Time-travel TV series' mighty publicity strategy. 260 (nearly 70\%) respondents showed that they hooked by the shows because those eye-pleasing actors. An all-star lineup has a powerful influence for a TV series. Timetravel TV series always catch this point. First, use the stars to catch viewers' eyes, and then make large-scale advertisement (Jean, 2000). More than 73\% students agree with "I had attracted by the large-scale of advertisement before watched". This propaganda way is an important reason for the success of time-travel TV series.

Only $144(38.7 \%)$ students disagree "Post-modern style conforms to the aesthetic idea of modern young people". Time-travel dramas are open in the plot and art style which caters to the requirements of novelty things and specific aesthetic ideas of modern young audience. The beauty of conflict about modern people and ancient environment brings to the young audience artistic enjoyment, which thought be specialist, is the key reason that people are crazy about time-travel TV dramas.

In this research, we find that only $16.9 \%$ respondents acknowledge that they like historical TV drama more than time-travel TV dramas. 243 (more than 65\%) students choose agree with "The content of time-travel TV 
series is entertaining". Compared with historical TV shows, the content of time-travel TV series is more entertainer and accessible. Time-travel TV series convey to the consumers the historical events through the set of modern techniques. This mode of representation attracts spectators in favor of the historical events and audiences with the preference for modern expressive techniques (Mitu, 2011). On contrast to historical-program stereotypes, time-travel TV series have a even wider audience. Although time-travel TV series is not the source of historical knowledge for most students, there are still $24.4 \%$ respondents learning history from time-travel TV series.

According to survey, 212 students (57\%) think time-travel TV dramas have some scientific basis, and 104 of them still believe that those stories in time-travel TV dramas could be happen in real life.

\section{Conclusion}

Time-travel drama is a new bright spot of contemporary TV dramas (Chao, 2012). It can bring people a feeling of traveling through time and space. It can also make people feel the breath of ancient, from the perspective of modern (Liu, 2010). However, time-travel TV dramas also cause a certain degree of damage to history and make audience addicted to the virtual world. It is necessary to establish the right perception of history, and distinguish fictional story, entertainment ingredients and real serious historical facts, which are critical to the education of the next generation.

All in all, as cultural products are welcomed by a wide range of audiences, time-travel TV dramas reflect the public's cultural demand orientation to some extent. For this kind of spiritual and cultural products, we should treat it correctly, and on the basis of its high quality and reasonable content, set aside some precious space for its development.

\section{Acknowledgements}

Supported by "the Fundamental Research Funds for the Central Universities" SWU1409164.

\section{References}

Cai, Q., \& Xu, X. (2012). A Study on Time-Travel TV Series from the Perspective of Narration. Modern Communication (Journal of Communication University of China), 5, 62-66.

Chao, Y. (2012). A Review on Time-Travel TV Series in Recent China. Science \& Technology for China's Mass Media, 16, 212-213.

Dong, X. (2011). The Reasons of Popularity of Time-Travel TV Series. Journalism Lover, 18, 83-84.

Jean, B. (2000). The Consumer Society (p. 135). Nanjing: Nanjing Press.

Jiang, Q. (2006). Fantasy and Reality: A Cultural Study of Science-Fiction Translation in Twentieth-Century China. Doctoral Dissertation, Shanghai: Fudan University.

Li, S., \& Guo, Y. (2012). The Time-Travel TV Series in 2011. Contemporary Cinema, 3, 98-101.

Li, W. (2012). Problems and Countermeasures of the Popular Time-Travel TV Series. Journal of Qiqihar Junior Teachers' College, 3, 88-89.

Liu, Y. (2010). Exploring the Phenomenon of Time-Traveling TV Series: A Summary of the Theoretical Symposium on TV Series "Shen Hua". Contemporary TV, 3, 36-38.

Mitu, B.-M. (2011). Culture and Television. The Television Globalization. Economics, Management, and Financial Markets, 6, 896-900.

Sun, S. (2011). Research on the Influence and Countermeasure of the Time-Travel TV Series Played on University Students' Values. Ideological \& Theoretical Education, 10, 86-89. 